\title{
Hereditary Nephritis: Early Clinical, Functional, and Morphological Studies
}

\author{
T. T. Antonovych, P.F. Deasy, L.U. Trna, J.B.D'Albora, \\ C.E. Hollerman, and P.L. Galgagno ${ }^{[81]}$ \\ Departments of Pathology and Pediatrics, School of Medicine Georgetown University, \\ and the Renal Division of Children's Hospital, Washington, D.C., USA
}

\section{Extract}

The accumulation of literature on hereditary nephritis with or without nerve deafness attests to the increased awareness of the existence of this syndrome. It is the purpose of this report to show that there are distinguishing histologic findings in young patients with minimal disease and normal renal function. Eleven patients were studied; 4 were females and 7 were males. Relevant family histories and clinical laboratory findings are shown in table I. In all patients, hematuria, gross or microscopic, was present. Exacerbations of the hematuria occurred as a part of the exaggerated response of these patients to upper respiratory infection. Renal functional data are shown in table II. These data were generally within normal limits for our laboratory. Table III outlines the morphologic findings observed on renal biopsy. In renal biopsies obtained from 10 patients, there was observed persistence of fetal-like glomeruli characterized by the circumferential crowding of visceral epithelium and an apparent decrease in the number of patent capillaries. The most striking finding in the tubules was the presence of red cells and red blood cell casts seen mainly in the distal and collecting tubules. Foam cells were an infrequent finding but, when present, were unassociated with interstitial fibrosis. Examination of kidney specimens under the electron microscope revealed the presence of at least three glomeruli in seven patients and of fetal-like glomeruli in all patients. There was also circumferential crowding of visceral epithelial cells, particularly at the surface, facing Bowman's capsule. These epithelial cells were characterized by large nuclei, small amounts of cytoplasm, apparently poorly developed intracytoplasmic organelles, and frequent villous-like cytoplasmic projections on the surface.

In families from whom past histories are unavailable, recognition of distinct renal biopsy characteristics would help identify this syndrome in the early stages of disease. At this stage, the combination of morphologic features considered to be characteristic would include the presence of a) fetal-like glomeruli, which were seen by electron microscopy in 7 patients and by light microscopy in 10 patients; b) mild to moderate hypercellularity; c) large numbers of tubules filled with red blood cells and red blood cell casts; and d) foam cells in the absence of interstitial fibrosis. The fetal-like glomeruli present in our patients did not correspond to any of the normal stages of glomerular development observed under electron microscopy by other investigators, but rather, appeared to represent dysgenesis. Most patients from whom data are reported were more than 2 years of age, at which time fetal glomeruli are exceptional. Of interest was the observation that almost identical histology was found to exist among the siblings. 


\section{Speculation}

The fetal-like glomeruli observed on renal biopsy might be the result of either a developmental abnormality or dysgenesis. The changes observed in all glomeruli studied by electron microscopy suggest that even those glomeruli that appear to be morphologically unchanged under light microscopy were involved in or by the pathologic process. It is suggested that there is a common rather than a diverse etiology for renal disease in children. Longitudinal follow-up with repeated renal functional studies and biopsies will be needed to delineate the natural history.

\section{Introduction}

The accumulation of literature on patients with hereditary nephritis with or without nerve deafness attests to the increased awareness of the existence of this syndrome. Clinical, genetic, and histologic data, which may lead to a more accurate definition of this condition, are being reported. This study purports to show that biopsies of young patients with minimal disease and normal renal function reveal distinguishing histologic findings.

\section{Case Material}

Data on a total of 11 cases form the clinical basis of this report. Five representative case histories are presented because the clinical material is similar.

Patient no. 2: This girl was one of three live born children, her mother having had three abortions. The patient weighed $2.466 \mathrm{~kg}$ at birth after normal delivery following a full-term pregnancy. At 2 years of age, a routine urinalysis showed microscopic hematuria. Bimonthly urinalyses during the ensuing 14 months revealed persistence of the asymptomatic hematuria (5-15 rbc/hpf). At approximately 4.5 years of age, she was admitted to the Children's Hospital of the District of Columbia (C.H.). Urologic examination, including cytoscopy and retrograde pyelography, failed to identify a cause of the hematuria; audiometric examination revealed bilateral conductive hearing loss. Two Addis count examinations on the mother at yearly intervals revealed significant microscopic hematuria. She subsequently refused further examination. The patient's younger brother, patient no. 1, had had gross hematuria since birth. Initial studies and reevaluation of both children are shown in tables I, II, and III.

Patient no. 3: This child was a white male, 2.5 years old. A routine urinalysis 1 week prior to hospitalization at C. H. showed hematuria and albuminuria. On admission, physical examination was unremarkable except for an elevated blood pressure, 148/90, which lasted less than $24 \mathrm{~h}$. He had no edema; his most recent sore throat had occurred 3 months prior to admission.
Further clinical studies are shown in tables I and II; renal biopsy findings are shown in table III. Microscopic hematuria had persisted with exacerbations at the time of upper respiratory disease.

Since birth, frequent urinalyses had been performed on patient no. 3 because at 6 years of age, his sister (patient no. 4) was found to have nephritis. Hematuria had occurred in the sister also at 2.5 years of age. Renal biopsy at another hospital had shown some glomeruli to have simplified capillary loops and crowding of the epithelial cells at the periphery. Periglomerular fibrosis and occasional fetal-like glomerulus were observed. The interstitium appeared to be slightly increased and some of the tubules atrophic. A number of tubules had contained protein casts and red blood cells. There was no further family history of renal disease.

Patient no. 6: At the age of 4.5 years, this white female was admitted to Georgetown University Hospital (G.U.H.) for evaluation of gross hematuria, which had persisted for 5 months following a 'flu-like' illness. She had been admitted to another hospital where evaluation had included IVP, cystoscopy, cystogram, urine cultures, and coagulation studies. No abnormality was detected by physical examination or by other studies. Following discharge, the hematuria continued. When she was readmitted to G.U.H., a family history of Bright's disease in a maternal aunt and deafness in the maternal grandmother was obtained. Renal function studies and a biopsy were undertaken (tables II and III). She subsequently had exacerbations associated with respiratory illness.

Patient no. 8: At 5 years of age, this girl was referred to G.H. for evaluation of asymptomatic hematuria, which had been discovered in a routine urinalysis 4 months previously. Since 21 years of age, her mother had had episodes of high fever, hematuria, and pyuria. This renal disease had been exacerbated during pregnancy, and it had been necessary to induce labor. Since adolescence, hearing had been impaired. There was a strong family history of renal disease in the mother's family, both in her generation and in that of her parents.

One of the patient's brothers had died at age 12 years. The autopsy report recorded 'evidence of renal 
damage, such as cell proliferation, sclerosis, and hyalinization'. In addition, capsular adhesions producing crescent-forming glomeruli, arteriolar sclerosis, and degenerative tubules (distended and atrophic) had been present; some had contained cellular inflammatory debris, and several had been filled with proteinaceous material and red blood cells. A few glomeruli had shown 'fetal' features; the interstitial tissues had been markedly increased in cortex and medulla. The brother had developed nephritis at 3 years of age, but was asymptomatic until 3 months prior to his death.

In patient no. 8, physical examination was unremarkable; the results of studies performed are shown in tables I, II, and III.

Patient no. 11: At 18 months of age, this white male was observed to have brown staining of his diaper. Six months later, a diagnosis of nephritis was made at another hospital. Persistence of hematuria and proteinuria without other symptoms prompted his referral at 3 years of age to G.U.H. for further investigation. At that time, an extensive history of renal disease and deafness through four generations was obtained (fig.l). Physical examination was unremarkable, and significant laboratory and histologic findings are shown in tables I, II, and III.

\section{Methods}

Blood urea nitrogen was determined by a modification [68] of the microdiffusion method [13]. Total protein in serum was determined by the refractometer method using an American Optical T.S. Meter. If the serum was found to be hypercholesterolemic, the method of GoRNALL [26] was employed. Electrophoresis of protein in serum was carried out by the Spinco method using a Durrum cell. Two-dimensional amino acid chromatography was performed according to a modified [5] method of DENT [15], and one-dimensional chromatography was performed by the method of EFRON [20]. Renal clearances of inulin and paraaminohippurate $(\mathrm{PAH})$ were determined using a constant infusion technique to maintain the level of inulin in serum at $20 \mathrm{mg} / 100 \mathrm{ml}$, and of $\mathrm{PAH}$ at $1-3 \mathrm{mg} /$ $100 \mathrm{ml}$. After a 90 -min equilibration period, four timed urine specimens were obtained by catheterization and 'air wash-out'. Specimens for determination of inulin and $\mathrm{PAH}$ in serum were obtained prior to infusion and during the first and last urine collection periods. Inulin was determined by a modification of the HUBBARD and Looms method [31], using the acid mixture for the hydrolysis of inulin. Para-aminohippurate was determined by use of the method of SMrTH [64]. Complement was ascertained by a quantitative immunodiffu-

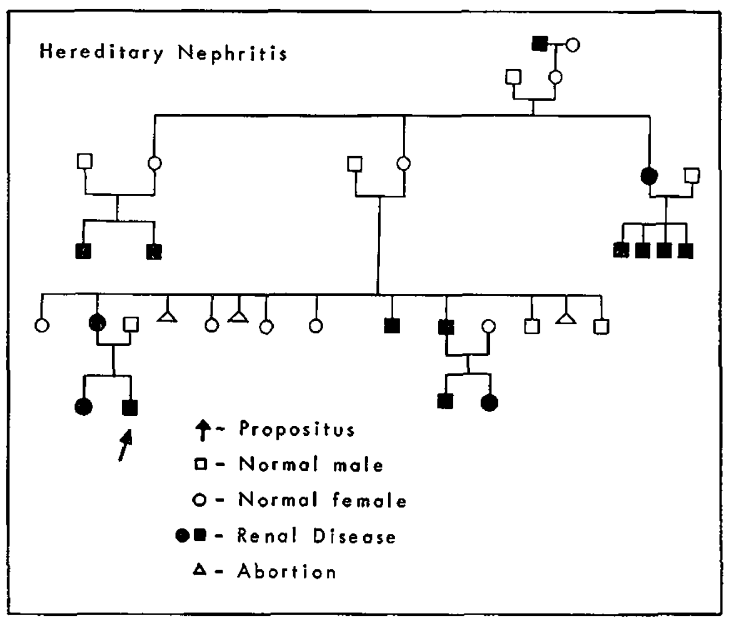

Fig.1. Pedigree of patient no. 11.

sion technique for assay of human complement G3 $\left(\beta_{1 \mathrm{c}} / \beta_{1 \mathrm{a}}\right.$-globulin) [78].

All renal biopsies were examined by light and electron microscopy. For light microscopy, paraffin sections of formalin-fixed tissue were cut at $3 \mu$ and stained with hematoxylin-eosin and methenamine silver, periodic acid-Schiff. For electron microscopy, small fragments of tissue were fixed immediately in $1 \%$ buffered osmic acid and imbedded in Epon 812. These sections were cut on the Porter-Blum microtome. Epon sections were treated with uranyl acetate. Electron micrographs were taken with a Phillips 75 electron microscope. In the specimens from each case, an average of three glomeruli were examined by electron microscopy. Audiometric evaluations were done using the standard pure tone threshold audiogram [79].

\section{Results}

The relevant family histories and clinical and laboratory findings of four female and seven male patients are shown in table I. Patients nos. 1 and 2 and patients nos. 3 and 4 were brother-sister pairs. The remainder were unrelated. The age at discovery of hematuria ranged from the newborn period to 8 years. In all patients, hematuria, gross or microscopic, was the presenting feature. Albuminuria was only slightly less constant, occurring in nine patients. Cylindruria was also present in nine patients. Pyuria was a frequent finding, but was always associated with negative urine cultures. Exacerbations of the hematuria occurred as part of the exaggerated response of these patients to upper respiratory infection. 
The blood urea nitrogen was normal $(<20 \mathrm{mg} / 100$ $\mathrm{ml}$ ) in all patients except in patient no. 10, whose clinical disease was known to have existed for at least 20 years. He also showed a minimal elevation in the level of cholesterol in serum together with a concomitant fall in the level of total protein. Levels of cholesterol and total protein in serum of other patients were normal. Electrophoresis of protein in serum performed on eight patients showed no abnormality. Serum complement determinations on eight patients at the time they were first seen showed no decrease. Antistreptolysin titers drawn at the time of first examination or at the time of an exacerbation, either singly or in pairs, failed to show a rise. There were no gross anatomical abnormalities found by intravenous pyelography or cystoscopy. Patients nos. 4 and 5 showed a minimal bladder neck contracture. None of the patients tested had an increase in urinary excretion of proline, a finding occasionally associated with this syndrome. Bleeding and coagulation studies were normal in all patients.

All patients had a family history of hematuria. Deafness, as recognized by the family without audiometric determination, was present in the families of six patients. Audiometric tests performed on the parents of patients nos. 3 and 4 showed hearing defects. Five of eight mothers questioned gave a history of abortion. Renal functional data are shown in table II. The age at the time of the study reflects varying duration

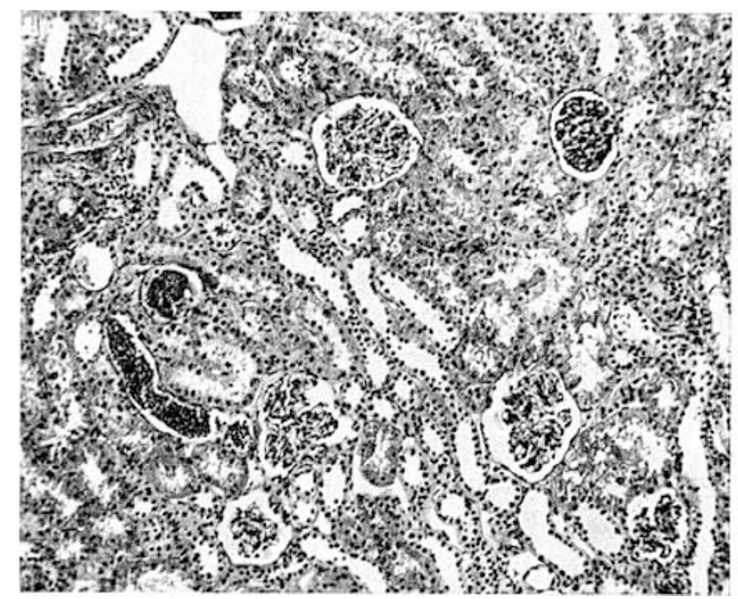

Fig. 2. This section shows one fetal-like, two focally hypercellular, and three relatively normal glomeruli. Two distal tubules filled with red blood cells are also seen (patient no. 11). Hematoxylin and eosin. $\times 100$.

Table II. Renal function ${ }^{1}$

\begin{tabular}{|c|c|c|c|c|c|c|}
\hline \multirow{2}{*}{$\begin{array}{l}\text { Patient } \\
\text { no. }\end{array}$} & \multirow[t]{2}{*}{ Sex } & \multirow{2}{*}{$\begin{array}{l}\text { Age, } \\
\text { years }^{2}\end{array}$} & \multicolumn{3}{|c|}{ Clearance } & \multirow{2}{*}{$\begin{array}{l}\text { Specific } \\
\text { gravity }^{3}\end{array}$} \\
\hline & & & Inulin & $\begin{array}{c}\text { PAH } \\
\mathrm{ml} / \mathrm{min} / 1.73 \mathrm{M}^{2}\end{array}$ & Creatinine & \\
\hline \multirow[t]{2}{*}{1} & M & 4 & $136^{4}$ & 484 & & 1.025 \\
\hline & & 5 & $148^{5}$ & 525 & & \\
\hline \multirow[t]{2}{*}{2} & $\mathrm{~F}$ & 5 & $120^{4}$ & 498 & & 1.026 \\
\hline & & 6 & $114^{5}$ & 490 & & \\
\hline 3 & $\mathbf{M}$ & 2.5 & 116 & 448 & & 1.025 \\
\hline 4 & $\mathrm{~F}$ & 6.5 & 105 & 463 & & 1.023 \\
\hline 5 & $\mathbf{M}$ & 2 & & & & 1.030 \\
\hline 6 & $\mathrm{~F}$ & 4.5 & 129 & 550 & & 1.025 \\
\hline 7 & $\mathrm{M}$ & 2.5 & 150 & 820 & & 1.017 \\
\hline 8 & $F$ & 5 & 147 & 455 & & 1.021 \\
\hline 9 & $\mathrm{M}$ & 11 & & & 110 & \\
\hline 10 & $\mathrm{M}$ & 21 & & & 144 & 1.018 \\
\hline 11 & $\mathrm{M}$ & 3 & 135 & 482 & & 1.016 \\
\hline
\end{tabular}

${ }_{1}$ Normal values $\left(\mathrm{ml} / \mathrm{min} / 1.73 \mathrm{M}^{2}\right)$ for males: inulin, $131 \pm 21.5 ; \mathrm{PAH}, 697 \pm 135.9$; for females: inulin, $117 \pm$ 15.6; PAH, $594 \pm 102.4$.

2 At time of study.

${ }^{3}$ Values for randomly excreted urine.

4 Initial studies.

5 Repeat studies. 


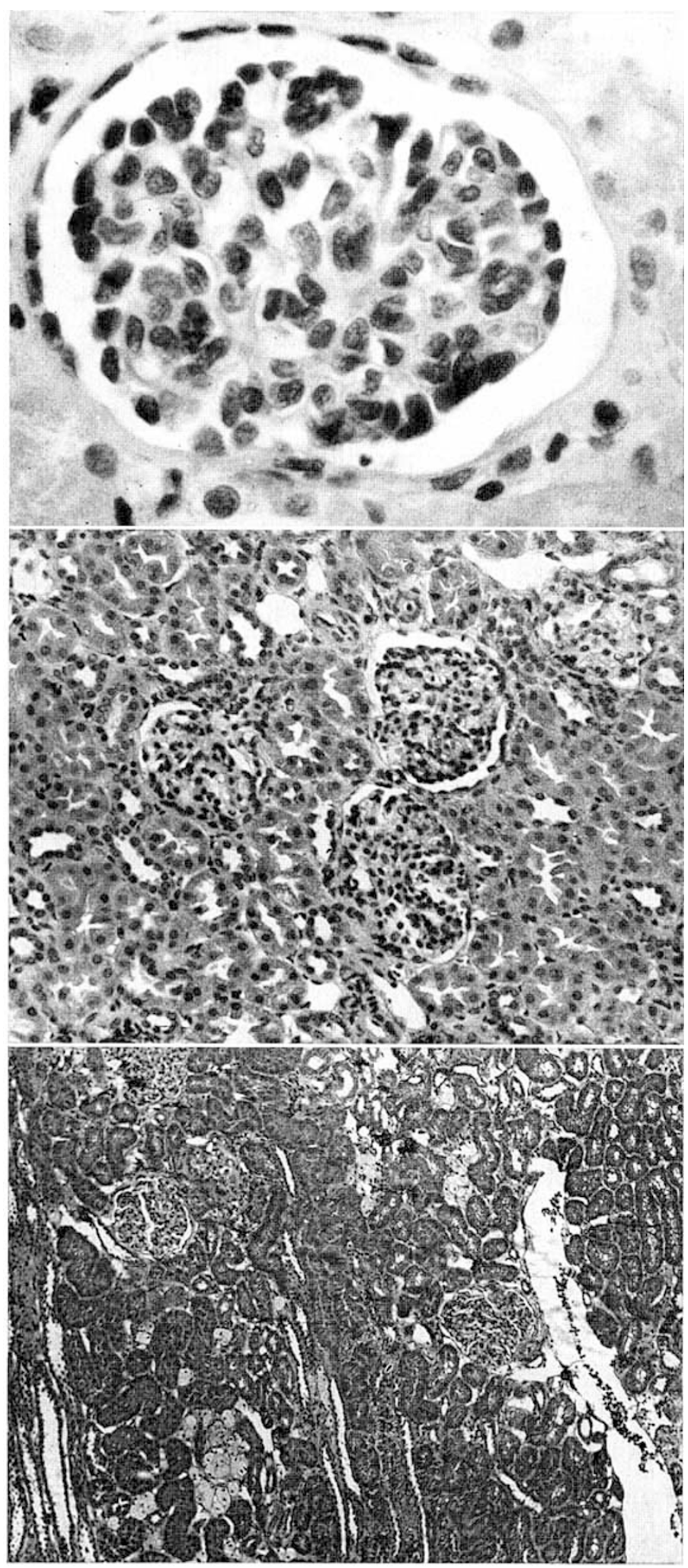

Fig. 3. This fetal-like glomerulus shows the characteristic circumferential crowding of visceral epithelium and an apparently reduced number of capillaries (patient no. 11). Hematoxylin and eosin. $\times 600$.

Fig.4. The three glomeruli seen show focal hypercellularity, capillary and capsular synechiae (patient no.3). Hematoxylin and eosin. $\times 245$.

Fig.5. This section shows foam cells in the interstitium, in the absence of fibrosis (patient no. 1). Hematoxylin and eosin. $\times 225$. 


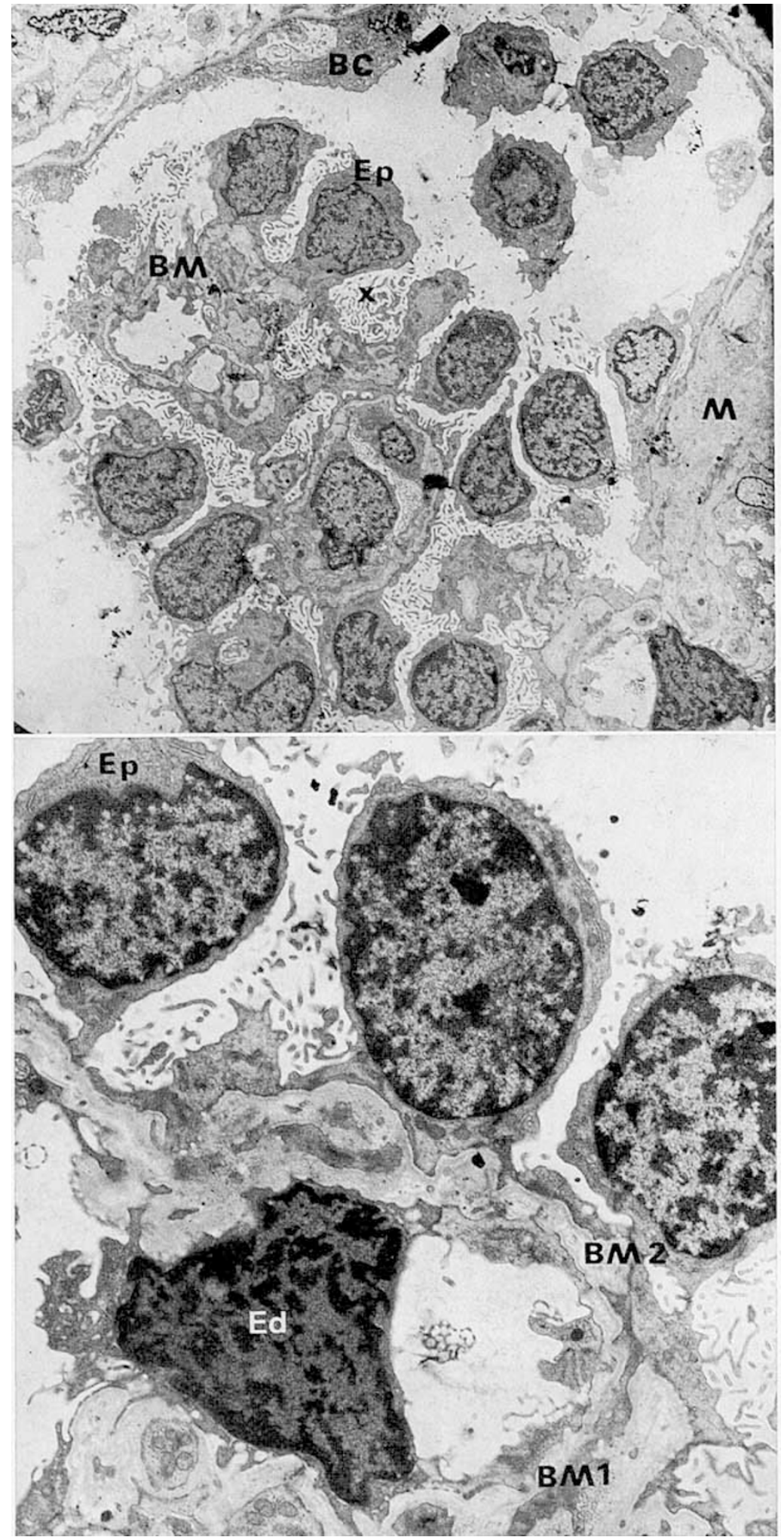

Fig.6. This portion of a glomerulus shows numerous visceral epithelial cells (Ep) lined up at the surface of the capillary loop. These have large nuclei, a comparatively small amount of cytoplasm, are attached by broad cytoplasmic masses to basement membrane $(\mathrm{BM})$ and show numerous microvilli $(X)$ filling much of the urinary space. On the left, Bowman's capsule $(\mathrm{BC})$ is seen, and on the right lower corner there is a mesangial area (M) showing increased amount of mesangial matrix (patient no. 3). $\times 1500$.
Fig.7. The epithelial cell (Ep) has a large nucleus and small amount of cytoplasm. The basement membrane is well formed and thin (BM1); in the adjacent loop (BM2) it is fibrillary and split. A hypertrophied endothelial cell (Ed) compresses the capillary lumen (patient no. 11). $\times 4000$. 
of disease (table I). These findings were generally within normal limits for our laboratory. Morphologic findings observed on renal biopsy are shown in table III. In all patients, light microscopy revealed definite though often mild glomerular changes, which were identical within individual families. Hypercellularity was mild, local, and focal, and was often confined to mesangial areas in most patients (fig. 2). In 10 patients, there was persistence of fetal-like glomeruli (figs. 2 and 3), characterized by circumferential crowding of visceral epithelium and an apparent decrease in the number of patent capillaries. Mild to moderate periglomerular fibrosis was often found, initially around the fetal-like glomeruli. Intercapillary and capsular synechiae (fig. 4) were seen in four patients. Focal basement membrane thickening was found in two patients.

The most striking finding in the tubules was the presence of red cells and red blood cell casts seen mainly in the distal and collecting tubules (fig.2). In many patients, there was a moderate increase in the interstitium around the distal tubule. Focal peritubular fibrosis, tubular degeneration, and atrophy were infrequent, significant only in patient no. 10, in whom disease was long-standing. Foam cells were an infrequent finding, but when present, were not associated with interstitial fibrosis (fig. 5). The renal blood vessels were generally normal, although mild arteriolar thickening was found in three patients.

Kidney specimens containing at least three glomeruli in 7 of the 11 patients were examined by electron microscopy; in all patients, fetal-like glomeruli were encountered. Circumferential crowding of visceral epithelial cells, particularly at the surface, facing Bowman's capsule, was also observed under light microscopy. These epithelial cells were characterized by large nuclei, small amounts of cytoplasm, apparently poorly developed intracytoplasmic organelles, and frequent villous-like cytoplasmic projections on the surface. The epithelial foot processes varied. The main body of the epithelial cells was often attached to the basement membrane by a broad cytoplasmic mass, but at the periphery, the foot processes became more slender (fig. 6).

The basement membrane varied also from capillary to capillary. In most areas it was very thin, measuring only about $1000-2000 \AA$ in thickness; the lamina densa and laminae rarae, interna and externa, were well defined. In other areas the membrane was wider, fibrillary, or apparently split (fig. 7). Basement membranelike material in the mesangial areas appeared to be somewhat increased, and the mesangial cells were prominent in places.

Some of the patients also showed moderate to marked swelling of endothelial cells. Occasional subendothelial deposits were encountered in two patients.
Occasional glomeruli showed hypertrophy and hyperplasia of parietal epithelial cells resulting in adhesions, a thickening of Bowman's capsule, and pericapsular fibrosis.

\section{Discussion}

The characterization of hereditary nephritis has undergone a gradual evolution since early descriptions of familial nephropathy in the latter part of the 19th century $[1,3,4,6,16,17,21,22,25,33,36,37,44,58$, 59, 71, 75]. In 1902, Guthrie [29] published the first pedigree, which was later reviewed in 1927 by ALPORT [2], who recognized deafness as part of the syndrome. Subsequently, in addition to describing similar pedigrees of familial hematuria and deafness, authors have reported the association of gross hematuria with a) upper respiratory infections $[3,8,9,11,48,55]$; b) the increased morbidity and mortality rate in males $[8,11$, $23,24,32,35,42,51,53,55,69,70]$; c) the high increase of abortions, toxemia, premature births and pyuria during pregnancy in affected females $[8,23,24,55$, $63,70]$; d) duplication of the ureters $[8,24,35,55$, $70]$; e) genetic patterns $[2,11,12,27,30,43,47,48$, $50-53,56,57,63,67,70,75,77]$; f) eye changes $[17$, $23,28,41,45,48,49,62,65,66] ; g)$ aminoaciduria $[19,48,61,74]$; h) neurological deficits $[42,55,61]$; and i) mental deficits $[19,48]$.

Perkoff $[51,53]$ considered pyuria to be the significant presenting sign in his pedigree and used autopsy data to support his clinical diagnosis of chronic interstitial pyelonephritis. A minority [8, 23] of authors agree with his opinion that the basic lesion is pyelonephritis, while the majority $[11,23,29,48,65,69,70]$ view it as a form of glomerulonephritis. Both schools have based their opinions primarily on autopsy material $[2,8-10,23,27,38,42,51,55]$, which represents end-stage disease. Little information on early renal changes has been reported. The description of biopsy material in the early stages of the disease $[8,46,50,54]$ suggests that little change is found in the glomerulispecifically, no characteristic features. Foam cells have been found $[23,51,55,63,76]$ at the corticomedullary junction, but the implications of this finding are equivocal, since similar cells are present in other forms of renal diseases [60]. Red cells in the renal tubules [11, 55] have also been reported to be present in the early stages of renal disease, sometimes as the sole abnormality in biopsy.

Recognition of this disease by characteristic renal biopsy criteria in the early stages of the disease would be most helpful in families for whom a past history is not available. At this stage, the combination of the morphologic features considered to be characteristic 
would include the presence of a) fetal-like glomeruli, which, in this study, were observed by electron microscopy in 7 patients and by light microscopy in 10 patients; b) mild to moderate hypercellularity; c) large numbers of tubules filled with red blood cells and red blood cell casts; and d) foam cells in the absence of interstital fibrosis.

The fetal-like glomeruli described in this report do not correspond to any of the normal stages of glomerular development observed by VERNIER et al. [72] by electron microscopy, but rather, appear to represent dysgenesis. Most patients from whom data are reported were more than 2 years of age, at which time the presence of fetal glomeruli is exceptional.

Other authors have found 'immature' glomeruli in Alport's syndrome [8], in the Fanconi syndrome [34, 40], and in congenital nephrosis [39]. The existence of these glomeruli in association with disease suggests that dysgenesis may be one of the possible mechanisms in the causation of hereditary nephritis.

Periglomerular fibrosis seems to appear first around the fetal-like glomeruli; later it progresses to hyalinization. A gradual progressive loss of nephrons ensues and accounts for the confusing histological picture reported by others in autopsy specimens. By light microscopy, the focal glomerular hypercellularity is indistinguishable from any other type of proliferative glomerulonephritis. Periglomerular fibrosis alone, although one of the features of pyelonephritis, is seen with glomerular obsolescence of any cause.

Most authors agree on the presence of red cells in the tubules. The quantity of red cells found seems to be disproportionately large considering the mild glomerular changes present. Permeability studies of fetal glomeruli indicate that fetal glomerular capillaries are more permeable than are adult capillaries $[38,72,73]$. Of interest in the present study has been the additional finding that almost identical histology occurs among siblings.

Foam cells were originally thought to be the diagnostic histologic feature of this condition [51]. Since the presence of foam cells has also been recognized in other diseases associated with the nephrotic syndrome, such as interstitial nephritis and pyelonephritis, it would appear that the presence of these cells in the later stages of hereditary nephritis would not be a diagnostic specificity [18]. In early biopsies, however, the presence of interstitial foam cells should make one suspicious of this disease.

Renal functional data based on crude tests [7-9, 14, $23,42,55,65]$ have shown no impairment in the early cases of this syndrome. Using more refined techniques in these studies, it was possible to confirm these findings and to correlate normal function with the minimal but distinctive histologic changes found on biopsy.
Summary

Salient factors in family history, clinical findings, functional data, and renal biopsy morphology were studied in 11 patients with hereditary nephritis. The results suggest that a particular combination of histological, changes may be found frequently in the early stages of this syndrome and would include the presence of a) fetal-like glomeruli; b) mild to moderate focal hypercellularity; c) large numbers of tubules filled with red blood cells; d) foam cells in the absence of interstitial fibrosis; and e) identical changes in siblings. The minimal histologic changes were not associated with abnormal renal functional studies.

\section{References and Notes}

1. Artken, J.: Congenital, hereditary and family hematuria. Lancet ii: 444-446 (1909).

2. Alport, A. G.: Hereditary familial congenital hemorrhagic nephritis. Brit. med. J. $i$ : 504-506 (1927).

3. AtTLEE, W.H.: Three cases of recurrent hematuria occurring in one family. St. Bartholomew's Hosp.J. 9: 41 (1901).

4. BENSON, A.H. : Nephritis of obscure origin in several children of one family. Lancet $i: 689$ (1893).

5. Brakel, H. und Souchon, K.: Die Papierchromatographie in der Kinderheilkunde (Enke, Stuttgart 1955).

6. Brill, N. E. and Lrbman, E.: A contribution to the subject of chronic interstitial nephritis and arteritis in the young, and family nephritis, with a note on calcification in the liver. J. exp. Med. 4: 541 (1899).

7. Gassady, G.; Brown, K. ; Cohen, M. and De MARIA, W.: Hereditary renal dysfunction and deafness. Pediatrics 35: 967 (1965).

8. Castleman, B. and Kibbee, B. U.: Case records of the Massachusetts General Hospital weekly clinico-pathological conference. New Engl.J.Med. 257: 1231-1237 (1957).

9. Chappell, J.A. and Kelsey, W. M. : Hereditary nephritis. Amer.J. Dis. Child. 99: 401-407 (1960).

10. Glark, N.S.: Familial renal insufficiency. Arch. Dis. Childh. 26: 351 (1957).

11. Clinico-pathological conference, The Children's Hospital Medical Center, Boston, Mass. J. Pediat. 68: 661-667 (1966).

12. Gohen, M.M.; Gassady, G. and Hanna, B.L.: Genetic study of hereditary renal dysfunction with associated nerve deafness. Amer. J. hum. Genet. 13: 379-389 (1961). 
13. Conway, E. J.: Microdiffusion analysis and volumetric error; in: Hawk, P.B.; OSER, B.L. and Summerson, W.H. Practical physiological chemistry, pp. 882-891 (Blakiston, Philadelphia/Toronto 1948).

14. GRoss, H.D.: Hereditary nephritis with unusual urea clearance. Case report. J. Maine med. Ass. 52: 366-368 (1961).

15. Dent, C. E.: A study of the behavior of some sixty amino-acids and other ninhydrin reacting substances on phenol-collidine filter paper chromatograms, with notes as to the occurrence of some of them in biological fluids. Biochem. J.43: 169 (1948).

16. Dickrnson, W.H.: Diseases of the kidney and urinary derangements. II, p.378 (Longmans Green, London 1875).

17. Eason, J.; Smith, G.L.M. and Bughanan, G.: Hereditary familial nephritis. Lancet $i i$ : 639-646 (1924).

18. Editorial: Hereditary nephropathy, deafness and renal foam cells. J. Amer. med. Ass. 180: 549 (1962).

19. Erron, M.L.: Familial hyperprolinemia. Report of a second case associated with congenital renal malformations, hereditary hematuria and mild mental retardation with demonstration of an enzyme defect. New Engl.J. Med. 272: 1243-1254 (1965).

20. Efron, M. L.; Young, D. ; Moser, H.W. and MaCGREADY, R. A.: A simple chromatographic screening test for the detection of disorders of aminoacid metabolism. New Engl.J. Med. 270: 1378 (1964).

21. Ferguson, J.N.: A case of family albuminuria. Brit.med.J. $i$ : 1689 (1910).

22. FRöLrch, T.: Zwei Fälle von hereditärer familiärer kongenitaler Nephritis. Jb. Kinderheilk. 64: 244 (1906).

23. Goldbloom, R.B.; Fraser, F.C.; Waugh, D.; Aranovitch, M. and Wrglesworth, F.W.: Hereditary renal disease associated with nerve deafness and ocular lesions. Pediatrics 20: 241 (1957).

24. Goldman, R. and Haberfelde, G. G.: Hereditary nephritis. Report of a kindred. New Engl.J. Med. 261: 734 (1959).

25. Goodheart, J.F. and Keating, J. M. : Acute and chronic Bright's disease; in Cyclopedia of diseases of children, vol.3, pp.532-558 (Lippincott, Philadelphia 1890).

26. Gornall, A.G.; Hardawill, G.J. and David, M.M.: Determination of the serum proteins by means of the biuret reaction. J. biol. Ghem. 177: 751 (1949).

27. Graham, J.B.: Chronic hereditary nephritis: Not shown to be partially sex-linked. Amer.J.hum. Genet. 12: 382-384 (1960).

28. GregG, J.B. and Becker, S. F.: Concomitant pro- gressive deafness, chronic nephritis and ocular lens disease. Arch. Ophthal., Chicago 69: 293 (1963).

29. Guthrie, L. G.: 'Idiopathic' or congenital, hereditary and familial haematuria. Lancet $i$ : 1243-1246 (1902).

30. Hamburger, J.; Crosnier, J.; Lissac, J. et NafFAH, J.: Sur un syndrome familial de néphropathie avec surdite. J. Urol. 62: 113-124 (1956).

31. Harrison, J.: Hydrolysis of insulin-modification of method of Hubbard and Loomis. Proc. Soc. exp. Biol. N.Y. 49: 111 (1942).

32. Hurst, A.F.: An address on the constitutional factor in disease. Ulster Med.Soc., November 17, 1924. Brit.med.J. i: 827 (1927).

33. Hurst, A.F.: Hereditary familial congenital haemorrhagic nephritis, occurring in individuals in three generations. Guy's Hosp. Rep. 73: 368-370 (1928).

34. Jackson, J.D.; Smith, F.G.; Litman, N.W.; Yulle, G.L. and Latta, H.: The Fanconi syndrome with cystinosis. Amer.J.Med. 33: 893 (1962).

35. Jornson, W.J. and HaGAN, P.J.: Hereditary nephropathy and loss of hearing. Arch. Otolaryng. 82: 166-172 (1965).

36. Kendall, G. and Hertz, A. G.: Hereditary familial congenital hemorrhagic nephritis. Guy's Hosp. Rep. 66: 137-141 (1912).

37. KIDD, J.: The inheritance of Bright's Disease of the kidney. Practitioner 29: 104-114 (1882).

38. Kurtz, S.M. and Feldman, J.D.: Experimental studies on the formation of the glomerular basement membrane. J. Ultrastruct. Res. 6: 19 (1962).

39. Lange, K.; Wachstein, M.; Wasserman, E.; Alptekin, F. and Slobody, L. : Congenital nephrotic syndrome. Amer. J. Dis. Child. 105: 338 (1963).

40. Latta, H.: Electron microscopic studies of renal disease. Calif. Med. 93: 272 (1960).

41. Loken, A. G.; Hanssen, O.; Halvorsen, S. and Jolster, N.J.: Hereditary renal dysplasia and blindness. Acta paediat. scand. 50: 170-184 (1960).

42. Marin, O.S.M. and Tyler, H.R.: Hereditary interstitial nephritis associated with polyneuropathy. Neurology, Minneap. 11: 999-1005 (1961).

43. MaKusick, V. A. : Pedigree of a family with hereditary nephritis. J. chron. Dis. 12: 174 (1960).

44. Meigs, A.V.: Clinical observations on albuminuria, based on a study of sixty-two cases seen in private practice. Trans. Coll. Physicians, pp. 163 179 (Philadelphia 1883).

45. Metrier, S.R.: Ocular defects associated with familial renal disease and deafness. Arch. Ophth. 65: 386 (1961).

46. Morin, M.; Gravelau, J.; Schimmel, H.; GreMX, F. et Testard, R.: Nephropathie hématurique familiale. Sem.Hôp., Paris 34: 907 (1958). 
47. Mulrow, P.J.: Hereditary nephritis: Report of a kindred. Amer.J. Med. 35: 737-748 (1963).

48. Oprtz, J.: Hereditary hematuria; in: J. Metcoff: Hereditary, developmental and immunologic aspects of kidney disease. Ann. Conf. on the Kidney, vol.XIII, p. 3-22 (The National Kidney Foundation. Northwestern University Press, Chicago, Ill. 1961).

49. Penrin, D. : Alport's syndrome, hereditary nephropathies with deafness and ocular changes. Ann. Oculist., Paris 197: 329-346 (1964).

50. Perkoff, G.T.; Nugent, C.A.; Dolowitz, D.A.; Stephens, F. E.: Carnes, W.H. and Tyler, F.H.: Follow-up study of hereditary chronic nephritis. Arch.intern. Med. 102: 733 (1958).

51. Perkoff, G.T.; Stephens, F.E.; Dolowitz, D.A. and TyLER, F.H.: Clinical study of hereditary interstitial nephritis. Arch.intern. Med. 88: 191200 (1951).

52. Perkoff, G.T.; Stephens, F.E. and Tyler, F.H.: Chronic hereditary nephritis and $\mathrm{Y}$ chromosome linkage: Reply to Graham (letter to the editor). Amer.J.hum. Genet. 12: 381 (1960).

53. Perkoff, G.T.: Familial aspects of diffuse renal diseases. Ann. Rev. Med. 15: 115-124 (1964).

54. Polr, M.: Néphropathie médicale bilatérale familiale à évolution chronique. Helv.med. Acta 22: 109-122 (1955).

55. Reyersbach, G. C. and Butler, A. M.: Congenital hereditary hematuria. New Engl.J. Med. 251: 377 (1954).

56. Rinkoff, S.S.; Stern, A. and Schumer, H.: Familial nephritis. Report of cases and review of literature. J.amer. med. Ass. 113: 661 (1939).

57. RobIn, E.D. and GaRdNER, F.H.: Hereditary factors in chronic Bright's disease: Study of two affected kindreds. Trans. Ass. amer. Physicians 70: 140 (1957).

58. Romme, R.: L'hérédité dans la néphrite chronique. Presse méd. 2: 362 (1899).

59. Samuelson, F.: Über hereditäre Nephritis und über den Hereditätsbegriff im Allgemeinen. Virchows Arch.path. Anat. 59: 257 (1874).

60. SANERKIN, N. G.: On the nature of interstitial foam cells in chronic glomerulonephritis. J. path. Bact. 86: 135 (1963).

61. SCRiver, C.: Hereditary nephropathy and deafness, hyperprolinemia and photogenic convulsions. Genetics Course, Bar Harbour 1961.

62. Senior, B.; Friedman, A. and Braudo, J. L.: Juvenile familial nephropathy with tapetoretinal degeneration. Amer.J. Ophthal. 65: 386 (1961).

63. Shaw, R.F. and Glover, R.A.: Abnormal segregation in hereditary renal disease with deafness. Amer.J.hum. Genet. 13: 89 (1961).
64. Smith, W.W.; Finkelstein, N. and Smith, H.W.: Renal excretion of hexitols (Sorbitol, Mannitol and Dulcitol) and their derivatives (Sorbitan, Isomanide and Sorbide), and of endogenous creatininelike chromogen in dog and man. J. biol. Chem. 135: 231 (1940).

65. Sohar, E.: Renal disease, inner ear deafness and ocular changes: New heredofamilial syndrome. Arch.intern. Med. 97: 627 (1956).

66. SoHAR, E.: A heredofamilial syndrome characterized by renal disease, inner ear deafness and ocular changes. Harefuah 47: 161 (1964).

67. Stephens, F.E.; Perkoff, G.T.; Dolowitz, D.A. and TYLER, F.H.: Partially sex-linked dominant inheritance of pyelonephritis. Amer. J. hum. Genet. 3: 303 (1951).

68. Strenttz, K.: Microdiffusion method of Conwaymodification. J.Lab. clin. Med. 25: 288 (1939).

69. Sturtz, G. S. and Burke, E. C. : Hereditary hematuria, nephropathy and deafness. New Engl. J. Med. 254: 1123 (1956).

70. Sturtz, G.S. and Burke, E. C.: Syndrome of hereditary hematuria, nephropathy and deafness. Proc. Mayo Glin. 33: 289 (1958).

71. TAYLOR, R.: Chronic interstitial nephritis in children. Minnesota Med. 3: 481 (1920).

72. Vernier, R.L. and Birch-Anderson, A.: Studies on human fetal kidney, development of the glomerulus. J. Pediat. 60: 754 (1962).

73. Vernier, R.L. and Birch-Anderson, A. : Permeability characteristics of the developing glomerulus. J. Ultrastruct. Res. 8: 66 (1963).

74. WALlACE, I.R. and JoNES, J.H. : Familial glomerulonephritis and amino aciduria. Lancet $i: 941$ (1960).

75. WeIss, E.: The congenital factor in chronic renal disease. J.amer. med. Ass. 79: 1097 (1922).

76. Whalen, R. E.; Huang, S.; Peschel, E. and McInTosh, H.D.: Hereditary nephropathy, deafness and renal foam cells. Amer. J. Med. 31: 171 (1961).

77. Whalen, R.E. and MaIntosh, H.D.: The spectrum of hereditary renal diseases. Amer.J. Med. 33: 282 (1962).

78. Hyland Division, Travenol Laboratories, Los Angeles, Calif.

79. Audiology Clinic, Gaullaudet College, Washington, D.C.

80. Supported by Public Health Service Research Grants nos. HE 5353, HD 00666 and AM-505058$05 \mathrm{~A} 1$.

81. Requests for reprints should be addressed to: PHIlip L. Galcagno, M.D., Georgetown University Hospital, 3800 Reservoir Road, N.W., Washington, D.C. 20007 (USA). 